\title{
Trends in inorganic and organic carbon in a bloom of Emiliania huxleyi in the North Sea
}

\author{
Erik Buitenhuis*, Judith van Bleijswijk, Dorothee Bakker, Marcel Veldhuis
}

Netherlands Institute for Sea Research, PO Box 59, 1790 AB Texel, The Netherlands

\begin{abstract}
During a survey of the end phase of an Emiliania huxleyi bloom in the northern part of the North Sea we measured total inorganic carbon (TIC) and the fugacity of $\mathrm{CO}_{2}\left(f \mathrm{CO}_{2}\right)$, as well as standing stocks of $\mathrm{CaCO}_{3}$ and particulate organic carbon (POC). Production of $\mathrm{CaCO}$ by $E$. huxleyi resulted in an immediate increase of $f \mathrm{CO}_{2}$, but led to a long-term decrease in $f \mathrm{CO}_{2}$. Observations during a surface survey and at $24 \mathrm{~h}$ stations showed a large increase of $f \mathrm{CO}_{2}$ with the standing stock of $\mathrm{CaCO}_{3}$. The immedrate increase of $\mathrm{fCO}_{2}$ is caused by a shift in the chemical equilibria in the inorganic carbon system when alkalinity decreases relative to dissolved inorganic carbon (DIC). Average $f \mathrm{CO}_{2}$ in the high reflectance area (with high numbers of detached coccoliths) was lower than average $\mathrm{fCO}_{2}$ in the reference areas, located outside the $E$. huxleyi bloom. The long-term decrease in $f \mathrm{CO}_{2}$ is due to an enhanced sedimentation of both organic and inorganic carbon in faecal pellets containing heavy calcite. This enhanced sedimentation is reflected in the vertical gradient of TIC between the surface mixed layer and the aphotic zone, which increased from the POC-rich zone to the $\mathrm{CaCO}_{3}$ maximum. The overall effect of production, air-sea exchange, mineralisation and sedimentation was a decrease of $f \mathrm{CO}_{2}$ due to a net transport of carbon to below the pycnocline. We tentatively calculate an atmospheric carbon sink of $1.3 \mathrm{~mol} \mathrm{~m}^{-2}$ for this bloom of E. huxleyi.
\end{abstract}

KEY WORDS: TIC $\cdot f \mathrm{CO}_{2} \cdot \mathrm{CaCO}_{3} \cdot \mathrm{POC} \cdot$ Algal bloom $\cdot$ Coccolithophorid

\section{INTRODUCTION}

Emiliania huxleyi (Lohmann) Hay \& Mohler is a coccolithophorid of the class of Prymnesiophyta. It is a unicellular alga that produces organic carbon through photosynthesis and inorganic carbon through coccolithogenesis. The coccoliths of $E$. huxleyi are oval platelets which are formed intracellularly by precipitation of $\mathrm{CaCO}_{3}$ in a coccolith vesicle (Westbroek et al. 1989). After completion they are transported out of the cell and retained on the cell surface.

Massive blooms of this species are a regular (yearly) phenomenon, especially in the temperate regions. Surface waters with spectral signatures similar to that of Emiliania huxleyi blooms annually covered an average of $1.4 \times 10^{6} \mathrm{~km}^{2}$ (Brown \& Yoder 1994). E. huxleyi may influence global climate with 3 mechanisms: (1) by affecting the inorganic carbon system of the sea water; (2) by altering the heat exchange between the sea

•E-mail: bhuis@nioz.nl water and the atmosphere, due to increased light scattering by detached coccoliths; and (3) by contributing to emissions of dimethylsulphide (DMS), which increases cloud albedo. In this paper we focus mainly on the first mechanism and to some extent on the second.

All algae contain the enzyme ribulose bisphosphate carboxylase oxygenase (Rubisco). Rubisco fixes $\mathrm{CO}_{2}$ into organic carbon (Eq, 1), which decreases the $\mathrm{CO}_{2}$ concentration in the sea water. Besides organic carbon, Emiliania huxleyi also produces $\mathrm{CaCO}_{3}$ (Eq. 2). Production of $\mathrm{CaCO}_{3}$ generates $\mathrm{CO}_{2}$ intracellularly (Eq. 3). The ratio between the production of organic carbon and $\mathrm{CaCO}_{3}$ determines the net effect on the $\mathrm{CO}_{2}$ concentration in the sea water. Production of organic carbon and $\mathrm{CaCO}_{3}$ in a ratio of $1: 1$ (Eq. 4 ) results in a small decrease of the $\mathrm{CO}_{2}$ concentration. This decrease is caused by the buffering effect of sea water: removal of bicarbonate is partially compensated for by hydration of $\mathrm{CO}_{2}$. The concentration of $\mathrm{CO}_{2}$ remains constant if the ratio is 1:1.2. Higher ratios result in elevated $\mathrm{CO}_{2}$ concentrations. 


$$
\begin{array}{ll}
\mathrm{CO}_{2}+\mathrm{H}_{2} \mathrm{O} & \rightarrow\left(\mathrm{CH}_{2} \mathrm{O}\right)_{\text {organic }}+\mathrm{O}_{2} \\
\mathrm{HCO}_{3}^{-}+\mathrm{Ca}^{2+} & \rightarrow \mathrm{CaCO}_{3}+\mathrm{H}^{+} \\
\mathrm{HCO}_{3}^{-}+\mathrm{H}^{+} & \rightarrow \mathrm{CO}_{2}+\mathrm{H}_{2} \mathrm{O} \\
2 \mathrm{HCO}_{3}^{-}+\mathrm{Ca}^{2+} & \rightarrow\left(\mathrm{CH}_{2} \mathrm{O}\right)_{\text {organic }}+\mathrm{CaCO}_{3}+\mathrm{O}_{2}
\end{array}
$$

Laboratory experiments have shown that the ratio between organic carbon and $\mathrm{CaCO}_{3}$ production is affected by the growth conditions of Emiliania huxleyi. $\mathrm{CaCO}_{3}$ production has been observed to exceed photosynthesis when cells are limited by phosphate (Paasche \& Brubak 1994, van Bleijswijk et al. 1994b). Such a situation may occur at the end of a bloom.

In the field the situation is complicated by the variability of environmental factors. Furthermore sedimentation may play an important role in the field, whereas it cannot be measured in the laboratory. Therefore no a priori conclusions can be drawn with respect to the effect of Emiliania huxleyi blooms on the $\mathrm{CO}_{2}$ concentration of surface waters. In order to resolve this question we measured the concentrations and standing stocks of carbon ( $f \mathrm{CO}_{2}, \mathrm{TIC}, \mathrm{CaCO}_{3}, \mathrm{POC}$ ) in various stages of a bloom of $E$. huxleyi in the summer of 1993 in the North Sea. We derive a carbon budget for the development of the bloom (in time) based on the various stages of the bloom encountered on a transect from the edge to the centre of the bloom (in space).

The fugacity of $\mathrm{CO}_{2}\left(f \mathrm{CO}_{2}\right)$ is proportional to the chemical activity $(\mu)$ of $\mathrm{CO}_{2}$ in air (equivalent to the activity of a dissolved ion). $f \mathrm{CO}_{2}$ is about $0.5 \%$ lower than the partial pressure of $\mathrm{CO}_{2}\left(\mathrm{pCO}_{2}\right.$, equivalent to the concentration of a dissolved ion). Total inorganic carbon (TIC) is the sum of dissolved inorganic carbon (DIC) and $\mathrm{CaCO}_{3}$. Calcium carbonate $\left(\mathrm{CaCO}_{3}\right)$ is precipitated by Emiliania huxleyi into coccoliths in the mineral form calcite (Young et al. 1991). Particulate organic carbon (POC) here designates the organic carbon in algae, calculated from flow cytometer data. Alkalinity is the excess of strong cations over strong anions or the amount of acid needed to titrate weak bases to their protonated forms. Alkalinity was calculated from DIC and $\mathrm{fCO}_{2}$.

\section{MATERIALS AND METHODS}

During a cruise in the northern part of the North Sea (Fig. 1A) from 28 June until 12 July 1993 total inorganic carbon (TIC), $f \mathrm{CO}_{2}$, standing stocks of $\mathrm{CaCO}_{3}$ and particulate organic carbon (POC) (see Table 1) were measured on board the research vessel 'Pelagia' For TIC, $\mathrm{fCO}_{2}$, and $\mathrm{CaCO}_{3}$, both discrete samples at CTD stations and on-line measurements, when the ship was sailing, were taken. For POC only discrete samples were taken.
Sampling. Discrete samples were taken from a CTD rosette sampler (Neil Brown) equipped with 10.5 l NOEX bottles. Samples were not poisoned; they were stored in the dark and analysed shortly after sampling. Discrete samples for TIC were taken in gas tight bags made of Mailar (aluminium foil coated with plastic) fitted with gas tight tubing (Masterflex 6542-24), TIC was measured within $2 \mathrm{~h}$ after sampling. Discrete samples for $\mathrm{fCO}_{2}$ were taken in $1100 \mathrm{ml}$ bottles of dark glass, which were flushed with 3 volumes of sea water. The $f \mathrm{CO}_{2}$ was measured within $1 \mathrm{~h}$ after sampling.

On-line samples for TIC were taken at approximately 10 min intervals from a $10 \mathrm{l}$ debubbling tank. This tank was flushed with water from the aqua flow system (flow approximately $81 \mathrm{~min}^{-1}$ ) which took in water at a depth of approximately $3 \mathrm{~m}$ at the bow of the ship. On-line samples for $f \mathrm{CO}_{2}$ were taken directly from the aqua flow system. Water temperature, salinity, fluorescence and atmospheric pressure were logged automatically at 1 min intervals.

Total inorganic carbon. Total inorganic carbon (TIC) was measured with an automated coulometer (DOE). Measurements were calibrated with standard water obtained from A. G. Dickson (Scripps Institution of Oceanography, CA, USA). The extraction efficiency as determined with this standard water was $99.3 \%$. The standard deviation was $8 \mu \mathrm{mol} \mathrm{kg}^{-1}(\mathrm{n}=19)$. This relatively large standard deviation was probably caused by variation between titration cells (A. A. J. Majoor, Netherlands Institute for Sea Research, NIOZ, The Netherlands, pers. comm.), which were not calibrated separately. All measurements at a station were performed with the same cell, probably leading to less variation.

Fugacity of $\mathrm{CO}_{2}$. The mole fraction of $\mathrm{CO}_{2}\left(\mathrm{xCO}_{2}\right)$ in air equilibrated with sea water was measured with an IRGA (infra-red gas analyser, Licor 6252). The instrument resembles the underway system described by Wanninkhof \& Thoning (1993), with 3 improvements (design by M. H. C. Stoll and J. M. J. Hoppema, NIOZ). (1) The $\mathrm{xCO}_{2}$ is measured in non-flowing gas to guarantee that measurements are taken at atmospheric pressure and to obtain a stable signal. Typical standard deviation of 10 measurements was 0.05 ppm. (2) During equilibration the gas is circulated through both the sample cell and the equilibrator. This prevents the flow of unequilibrated air into the system which Wanninkhof \& Thoning (1993) mentioned as a possible source of error. (3) Measurements were performed in dry gas to circumvent the need for water vapour correction, and to facilitate comparison between samples and calibration gases.

The IRGA was calibrated every hour with 3 mixtures of $\mathrm{CO}_{2}$ in synthetic air. The raw data were fitted by a second order function. The polynomial function sup- 

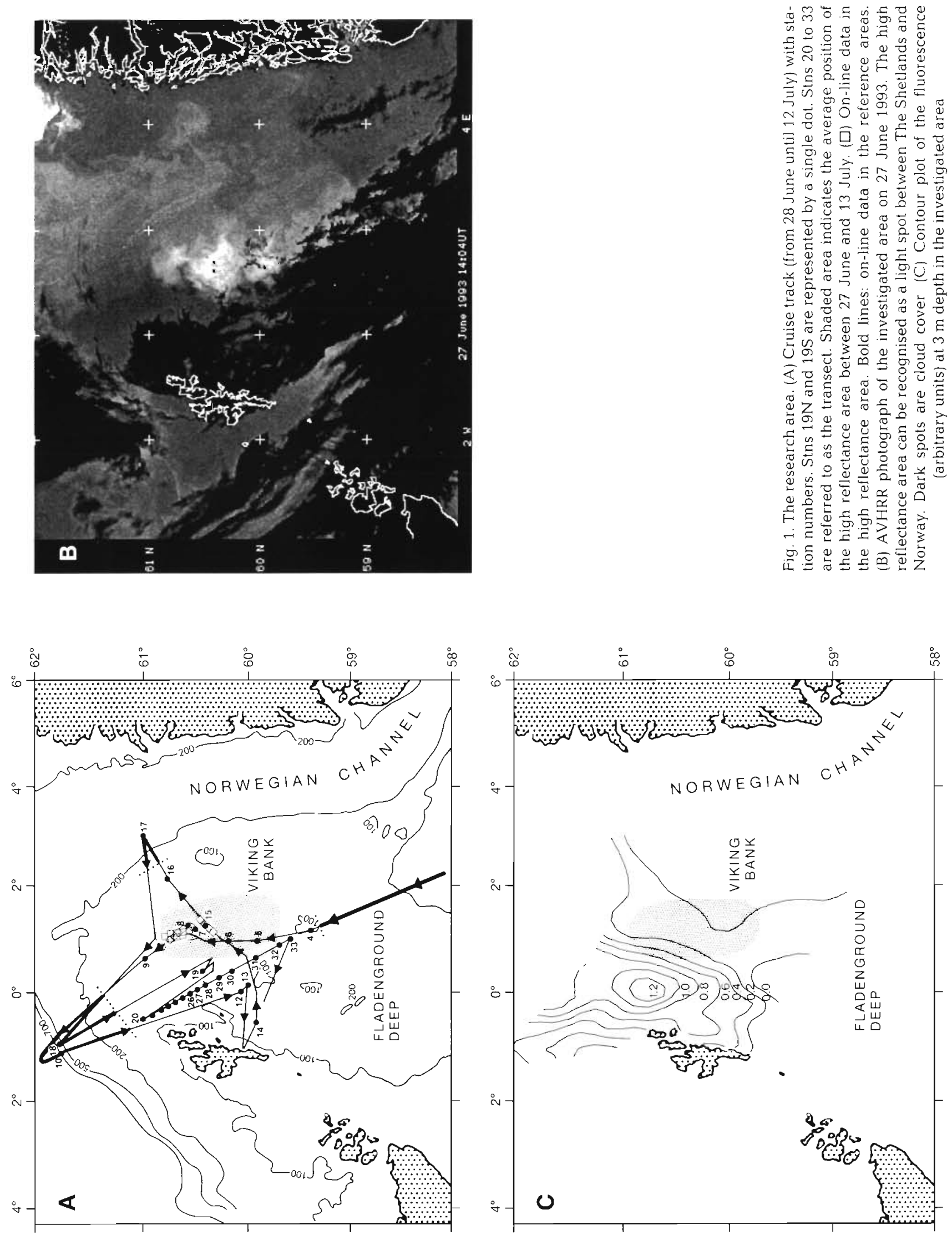
plied by the manufacturer gives less reproducible results for $\mathrm{xCO}_{2}$, because the zero and span settings vary with changes in pressure and temperature (F. A. Koning, NIOZ, pers. comm.)

The 3 calibration gases were calibrated on a gas chromatograph (GC) against 3 standards of the NMI (Dutch Bureau of Standards). Similarly, a calibration gas of NOAA (National Oceanographic and Atmospheric Administration, USA) was measured on the GC. The difference between the measured value based on the NMI calibration and the value given by NOAA was $+1.3 \mathrm{ppm}$. The reproducibility of the IRGA, calculated as the standard deviation of air samples ( $n=133$ ), was 1.2 ppm.

Discrete samples for $\mathrm{xCO}_{2}$ were measured in bottles of dark glass after equilibration of 1 I sea water with $100 \mathrm{ml}$ laboratory air plus the volume of air in the instrument. On-line samples were taken by equilibrating a circulated flow of air with a continuous flow of sea water from the aqua flow system (approximately 21 $\mathrm{min}^{-1}$ ) in an equilibrator equipped with a calibrated temperature sensor. The design of the equilibrator was adopted from A. Watson (Robertson et al. 1993). Every hour we measured 10 samples from the sea water equilibrator and 1 sample of air, taken at about $15 \mathrm{~m}$ above the sea surface.

For the discrete samples, $f \mathrm{CO}_{2}$ was calculated using $\mathrm{xCO}_{2}$, the temperature measured by the CTD and the ambient pressure (Weiss 1974). This calculated $f \mathrm{CO}_{2}$ was higher than the in situ $\mathrm{fCO}_{2}$ due to warming of the samples. We estimate an increase of less than $10 \mu$ atm for surface samples and less than 60 patm for samples taken at $125 \mathrm{~m}$.

For the on-line samples, $f \mathrm{CO}_{2}$ in the equilibrator was calculated using the temperature in the equilibrator and the ambient pressure. $f \mathrm{CO}_{2}$ at the in situ temperature was calculated from TIC and alkalinity according to Goyet et al. (1993). The use of TIC instead of DIC introduced an error smaller than 0.1 uatm. TIC at the time of measurement of $\mathrm{fCO}_{2}$ was obtained by linear interpolation. Alkalinity was calculated using TIC and $\mathrm{fCO}_{2}$ in the equilibrator.

Dissolved inorganic carbon and alkalinity. Dissolved inorganic carbon (DIC) was calculated by subtracting $\mathrm{CaCO}_{3}$ from TIC. Alkalinity was calculated from DIC and $f \mathrm{CO}_{2}$, using the dissociation constants of Goyet \& Poisson (1989). The uncertainty in alkalinity due to the standard deviation of $8 \mu \mathrm{mol} \mathrm{kg}{ }^{-1}$ in TIC is about 10 pequivalents $\mathrm{kg}^{-1}$. The uncertainty due to the standard deviation of $1.2 \mathrm{ppm}$ in $f \mathrm{CO}_{2}$ is about 1 uequivalent $\mathrm{kg}^{-1}$

Standing stock of $\mathrm{CaCO}_{3}$. Particulate calcium $(>0.8 \mu \mathrm{m})$ standing stock was determined according to van Bleijswijk et al. (1994a) using atomic absorption spectroscopy. The reproducibility of the measurements (average standard deviation of duplicates) was 6\%. The $\mathrm{CaCO}_{3}$ standing stock was calculated from particulate calcium by assuming a 1:1 Ca:C molar ratio in coccoliths (K. M. Fagerbakke, University of Bergen, Norway, pers. comm.).

Dissolution of $\mathrm{CaCO}_{3}$. The dissolution rate of $\mathrm{CaCO}_{3}$ was determined by incubating 5 l of sea water in the dark. Duplicate samples were taken in the dark from single 10.5 I NOEX bottles. Samples were incubated unfiltered or after filtration over 10 and $200 \mu \mathrm{m}$ filters to remove micro- and mesozooplankton respectively. Samples were incubated in a sea water tank on deck of the ship. Subsamples were taken after 0, 24 and 48 or $72 \mathrm{~h}$, until the bottles were empty. Three series of subsamples in which a decrease in $\mathrm{CaCO}_{3}$ alternated with an increase were discarded. Apparently the bottles had not been shaken sufficiently to resuspend the coccoliths and algae before taking one of the subsamples.

Saturation of sea water with $\mathrm{CaCO}_{3}$. The concentra-

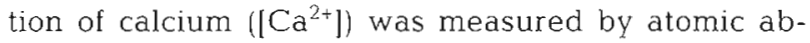
sorption spectroscopy. The concentration of carbonate ( $\left[\mathrm{CO}_{3}{ }^{2-}\right]$ ) was calculated from DIC and $f \mathrm{CO}_{2}$, using the dissociation constants of Goyet \& Poisson (1989). The extent of oversaturation of $\mathrm{CaCO}_{3}$ in sea water was calculated according to Mucci (1983).

Particulate organic carbon. Particulate organic carbon (POC) standing stock of the phytoplankton was calculated from cell numbers and estimated spherical diameters (ESDs), as determined by flow cytometry (Veldhuis et al. in press). ESD was calibrated with standard beads (high density 2.0 and $10.0 \mu \mathrm{m}$, Coulter Counter), and checked by fractionated filtration and microscopical observations. ESDs were used to estimate cell volumes (assuming spherical cells), that were converted to carbon. For cyanobacteria a constant fac-

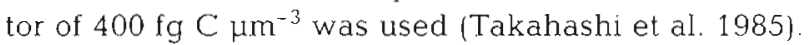
For pico-eukaryotes a factor of 1800 to $3000 \mathrm{fg} \mathrm{cell}^{-1}$ was used, depending on size (Campbell \& Vaulot 1993). For larger cells the formula $\log C=-0.422+$ $0.758 \log V$ was used (Strathmann 1967). Detritus was not included

\section{RESULTS}

\section{Research area}

Before the start of the cruise the research area was located by AVHRR (advanced very high resolution radiometry). An area with high reflectance was observed in the North Sea. During the cruise this area was located east of the Shetland Islands (Fig. 1B). The high reflectance area could be recognised from the ship as a milky white colouring of the sea. It was characterised by low nutrient concentrations $\left(\mathrm{NO}_{3}^{-}\right.$and 
$\mathrm{PO}_{4}{ }^{3-}<0.1 \mu \mathrm{mol} \mathrm{l}^{-1}$ ), low particulate organic carbon $\left(-4 \mu \mathrm{mol} \mathrm{l^{-1 }} \mathrm{POC}\right)$, low numbers of living Emiliania huxleyi $\left(\sim 2000 \mathrm{ml}^{-1}\right)$ and high numbers of detached coccoliths $\left(\sim 100000 \mathrm{ml}^{-1}\right)$. These conditions are typical for the end phase of a bloom of E. huxleyi. Small cyanobacteria $\left(\sim 100000 \mathrm{ml}^{-1}\right)$ contributed about $50 \%$ to POC.

To the northwest of the high reflectance area we observed a POC-rich zone (cf. Fig. 1C). This zone was characterised by high nutrient concentrations ( $4 \mu \mathrm{mol}$ $\mathrm{l}^{-1} \mathrm{NO}_{3}{ }^{-}, 0.3 \mu \mathrm{mol} \mathrm{l}^{-1} \mathrm{PO}_{4}{ }^{3-}$ ) and a high standing stock of POC $\left(\sim 30 \mu \mathrm{mol} \mathrm{l}^{-1}\right)$. A mixed phytoplankton community was present, with Emiliania huxleyi $\left(\sim 3500 \mathrm{ml}^{-1}\right)$ constituting about $40 \%$ of POC.

In the Atlantic Ocean and to the east and south of the high reflectance area nutrient concentrations $(0.1$ to $6 \mu \mathrm{mol} \mathrm{l}^{-1} \mathrm{NO}_{3}{ }^{-}$and 0.1 to $\left.0.4 \mu \mathrm{mol} \mathrm{l}^{-1} \mathrm{PO}_{4}{ }^{3-}\right)$ and $\mathrm{POC}$ ( 2 to $15 \mathrm{\mu mol}^{-1}$ ) were variable. In these areas, which we will call the reference areas (Fig. 1A), the numbers of Emiliania huxleyi cells $\left(\sim 2000 \mathrm{ml}^{-1}\right)$ and detached coccoliths $\left(\sim 16000 \mathrm{ml}^{-1}\right)$ were low.

\section{On-line measurements}

Total inorganic carbon (TIC; Table 1) averaged $2048 \pm 31 \mu \mathrm{mol} \mathrm{kg}{ }^{-1}(\mathrm{n}=172)$ in the high reflectance area, and $2058 \pm 31 \mu \mathrm{mol} \mathrm{kg} \mathrm{kg}^{-1}(\mathrm{n}=182)$ in the reference areas. TIC varied between 1970 and $2110 \mu \mathrm{mol}$ $\mathrm{kg}^{-1}$ in both areas. $\mathrm{fCO}_{2}$ in the high reflectance area was $303 \pm 24$ Hatm on average $(n=464$, ranging from 257 to $440 \mu \mathrm{atm})$. In the reference areas $\mathrm{fCO}_{2}$ was $324 \pm 29$ uatm on average $(n=416$, ranging from 227 to 421 uatm).

Apparently, the 2 regions, while showing large differences in detached coccoliths, do not show significant differences in average TIC and $\mathrm{fCO}_{2}$. However, we found a positive correlation between $\mathrm{fCO}_{2}$ and online $\mathrm{CaCO}_{3}$ standing stock measured at the same time $\left[f \mathrm{CO}_{2}(\mu \mathrm{atm})=259.7+3.5 \mathrm{CaCO}_{3}(\mu \mathrm{mol}]^{-1}\right), \mathrm{n}=94, \mathrm{p}<$ $0.05]$. When $\mathrm{fCO}_{2}$ was corrected to a constant temperature of $10.6^{\circ} \mathrm{C}$ it increased slightly less with
$\mathrm{CaCO}_{3}\left[\mathrm{Fig} 2 ; f \mathrm{CO}_{2}\right.$-corrected (Hatm) $=260.0+$ $\left.3.0 \mathrm{CaCO}_{3}\left(\mu \mathrm{mol} \mathrm{l}{ }^{-1}\right), \mathrm{n}=94, \mathrm{p}<0.05\right]$. We also observed a positive correlation between temperature and $\mathrm{CaCO}_{3}$ standing stock $\left[\mathrm{T}\left({ }^{\circ} \mathrm{C}\right)=10.6+0.03 \mathrm{CaCO}_{3}\right.$ $\left(\mu \mathrm{mol} \mathrm{l}{ }^{-1}\right), n=94, p<0.02$ ]. Ackleson et al. (1988) and Holligan et al. (1993) found a much larger temperature difference between $\mathrm{CaCO}_{3}$-rich and $\mathrm{CaCO}_{3}$-poor waters.

The mole fraction of $\mathrm{CO}_{2}\left(\mathrm{xCO}_{2}\right)$ in dry air was 358.8 $\pm 1.2 \mathrm{ppm}$ ( $\mathrm{n}=133$ ) during the first week of the cruise. The same average $\mathrm{xCO}_{2}$ was presented in Boden et al. (1994) for June 1993 north of $35^{\circ} \mathrm{N}(357.6 \pm 3.7, \mathrm{n}=8$, excluding the data of the industry-influenced Waldhof station). $f \mathrm{CO}_{2}$ in the air, at a pressure of $1.013 \times 10^{5} \mathrm{~Pa}$ and an average water temperature of $11.6^{\circ} \mathrm{C}$, was $357.5 \mu \mathrm{atm}$.

\section{$24 \mathrm{~h}$ stations}

At four 24 h stations (Stns 12, 19N, 19S and 15; Fig. 1A) we measured several vertical profiles of TIC, $\mathrm{fCO}_{2}, \mathrm{CaCO}_{3}$ and $\mathrm{POC}$ over a $24 \mathrm{~h}$ period. The position of the ship was maintained in relation to the sam-

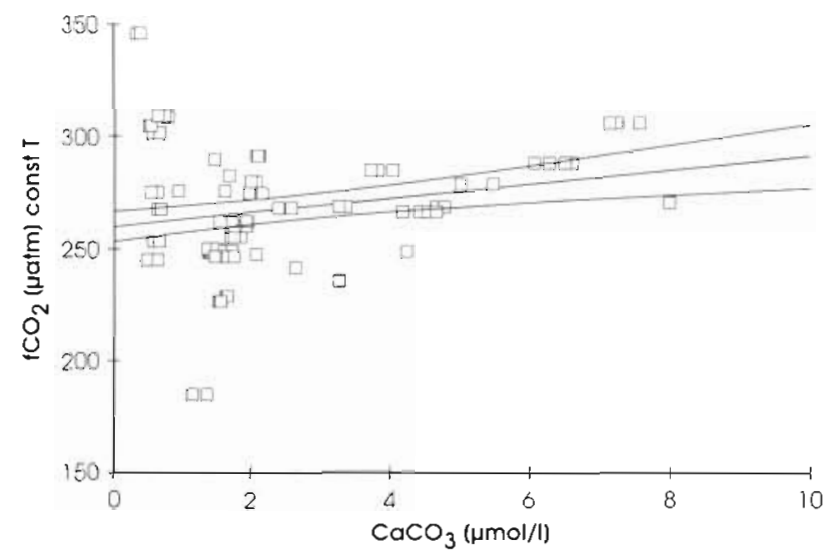

Fig. 2. Plot of fugacity of $\mathrm{CO}_{2}\left(f \mathrm{CO}_{2}\right)$, corrected to a constant temperature of $10.6^{\circ} \mathrm{C}$, versus $\mathrm{CaCO}_{3}$. Linear regression with $95 \%$ confidence levels, $f \mathrm{CO}_{2}=260.0+3.0 \mathrm{CaCO}_{3} n=94$, $\mathrm{p}<0.05$

Table 1. Parameters mentioned in this paper

\begin{tabular}{|c|c|c|c|}
\hline Parameter & Abbreviation & Unit & Description \\
\hline Alkalinity & & Hequivalents $\mathrm{kg}^{-1}$ & $2\left[\mathrm{CO}_{3}{ }^{2-}\right]+\left[\mathrm{HCO}_{3}{ }^{-}\right]+\left[\mathrm{B}(\mathrm{OH}]_{4}^{-}\right]+\left[\mathrm{OH}^{-}\right]-\left[\mathrm{H}^{+}\right]$etc. \\
\hline Calcite & $\mathrm{CaCO}_{3}$ & $\mu$ mol $1^{-1}$ & Particulate $\mathrm{Ca}(>0.8 \mu \mathrm{m})$ \\
\hline Chlorophyll a & & $\mu \mathrm{g} \mathrm{l^{-1 }}$ & Measured fluometrically or with HPLC \\
\hline Dissolved inorganic carbon & DIC & $\mu \mathrm{mol} \mathrm{kg}-1$ & {$\left[\mathrm{HCO}_{3}{ }^{-}\right]+\left[\mathrm{CO}_{3}^{--}\right]+\left[\mathrm{CO}_{2}\right]$} \\
\hline Fugacity of $\mathrm{CO}_{2}$ & $\mathrm{fCO}_{2}$ & $\mu \mathrm{atm}$ & Activity of $\mathrm{CO}_{2}$ gas in water \\
\hline Mole fraction of $\mathrm{CO}_{2}$ & $\mathrm{xCO}_{2}$ & ppm & Gas mixing ratio ( $\mu \mathrm{mol} \mathrm{mol}^{-1}$ ) \\
\hline Particulate organic carbon & $\mathrm{POC}$ & $\mu \mathrm{mol} \mathrm{l}^{-1}$ & Phytoplankton carbon (flow cytometer) \\
\hline Total inorganic carbon & $\mathrm{TIC}$ & $\mu \mathrm{mol} \mathrm{kg}{ }^{-1}$ & {$\left[\mathrm{HCO}_{3}^{-}\right]+\left[\mathrm{CO}_{3}^{--}\right]+\left[\mathrm{CO}_{2}\right]+\left[\mathrm{CaCO}_{3}\right]$} \\
\hline
\end{tabular}


pled water mass by using a drifting buoy with sediment traps at 10 and $50 \mathrm{~m}$ depth. Stn 12 was located just outside the high reflectance area. To the west of the high reflectance area there were two $24 \mathrm{~h}$ stations on the same day (sampled alternatingly). One (Stn 19N) was located in the POC-rich zone, and the other (Stn 19S) was located 9 nautical miles to the south, towards the high reflectance area. The fourth $24 \mathrm{~h}$ station (Stn 15) was in the high reflectance area.

At none of the stations did $f \mathrm{CO}_{2}$ or TIC show a distinct diel rhythm. In order to better distinguish the differences between stations, data of all CTD casts were averaged to produce a single profile per station. We order these stations as progressive stages of the bloom: first the reference areas, then the POC-rich zone and then the high reflectance area (successively Stns 12, $19 N, 19 S$ and 15). During these stages concentrations of TIC decreased in the upper mixed layer (from 2070 to $2060 \mu \mathrm{mol} \mathrm{kg}^{-1}$ ). In contrast, below the pycnocline TIC increased (from 2120 to $2150 \mu \mathrm{mol} \mathrm{kg}{ }^{-1}$ ) (Fig. 3A). These observations indicate that sedimentation was higher in the high reflectance area than in the reference areas. Sedimentation decreases TIC in the upper mixed layer, and subsequent mineralisation below the pycnocline increases TIC. The $f \mathrm{CO}_{2}$ increased from Stn 12 to Stn 15 over the entire water column (from 286 to $354 \mu \mathrm{atm}$ at the surface, Fig. 3B). Stns $19 \mathrm{~S}$ and $19 \mathrm{~N}$ showed intermediate values.
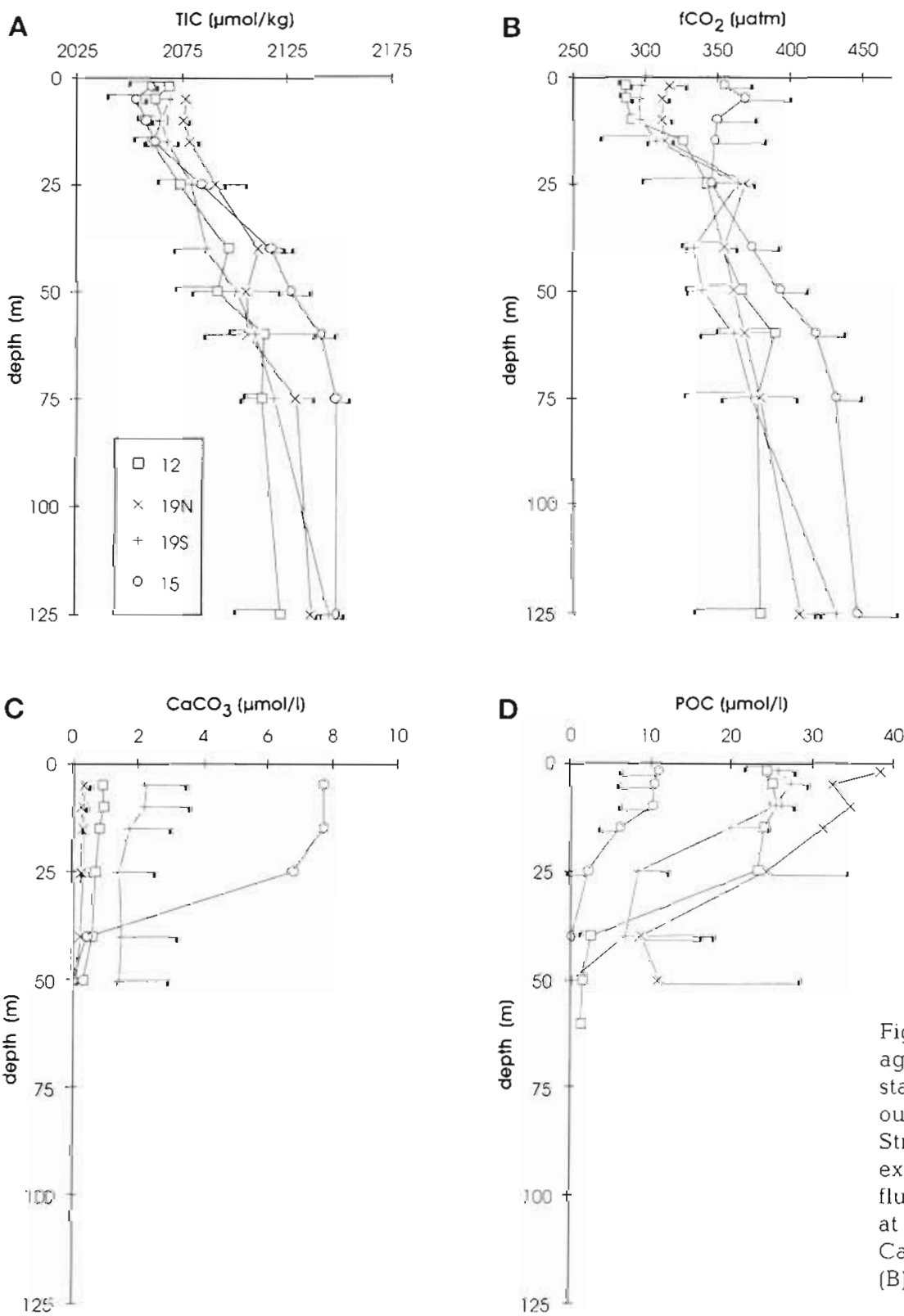

Fig. 3. Depth profiles of $24 \mathrm{~h}$ stations, averaged values over all CTD casts at a single station, with standard deviations. (ㅁ) St.n 12 outside the bloom $\left(n=3 \text {, except } \mathrm{CaCO}_{3}\right)_{i}(x)$ Stn $19 \mathrm{~N}$, at the fluorescence maximum $(n=3$, except $\left.\mathrm{CaCO}_{3}\right) ;(+) \mathrm{Stn}$ 19S, at the lower fluorescence $\left(n=4\right.$, except $\left.\mathrm{CaCO}_{3}\right) ;(0)$ Stn 15 , at the high reflectance area $(n=5$, except $\mathrm{CaCO}_{3}$ ). (A) Total inorganic carbon, TIC; (B) $f \mathrm{CO}_{2} ;$ (C) $\mathrm{CaCO}_{3}$; (D) POC $(n=1$ or 2 for Stns 19N, 19S) 
The standing stock of $\mathrm{CaCO}_{3}$ increased from Stn $19 \mathrm{~N}$ via $19 \mathrm{~S}$ to Stn 15 , whereas the standing stock of POC decreased (Fig 3C, D). At Stn 12 the standing stocks of $\mathrm{CaCO}_{3}$ and $\mathrm{POC}$ were intermediate between those at Stns $19 \mathrm{~N}$ and $19 \mathrm{~S}$.

At Stn 15 a high standing stock of $\mathrm{CaCO}_{3}\left(8 \mu \mathrm{mol} \mathrm{l}^{-1}\right)$ and a low standing stock of POC $\left(11 \mu \mathrm{mol} \mathrm{^{-1 }}\right)$ coincided with a high $f \mathrm{CO}_{2}$ (354 $\mu$ atm at the surface). Most likely, this high $f \mathrm{CO}_{2}$ is the result of the acidification of the sea water due to $\mathrm{CaCO}_{3}$ production (Eqs. 2 \& 3). At another station in the high reflectance area ( $\operatorname{Stn} 7$. Fig. $1 \mathrm{~A})$ a high $\mathrm{CaCO}_{3}$ standing stock $\left(15 \mu \mathrm{mol} \mathrm{l}^{-1}\right)$ and low POC (4 $\mu \mathrm{mol} \mathrm{l^{-1 }}$ at the surface) coincided with a

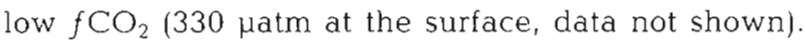
The vertical gradient in TIC $\left(2040 \mu \mathrm{mol} \mathrm{kg}^{-1}\right.$ at the surface; $2150 \mu \mathrm{mol} \mathrm{kg}^{-1}$ at $125 \mathrm{~m}$ depth) was even sharper here than at $\operatorname{Stn} 15$. We conclude that so much carbon was removed from the upper mixed layer through sedimentation that this had a greater effect on $\mathrm{fCO}_{2}$ than did the production of coccoliths.

\section{Dissolution experiments}

At Stns 7, 12 and 15 (Fig. 1A) samples were incubated in the dark for determination of the dissolution rate of $\mathrm{CaCO}_{3}$. In order to determine the effect of grazing on the dissolution rate we compared samples that had been filtered before incubation (either 10 or $200 \mu \mathrm{m}$ ) with unfiltered samples. Removal of grazers had no significant effect on the dissolution rate of $\mathrm{CaCO}_{3}$ (data not shown). Therefore the results were averaged per station (Fig. 4). At all stations 25\% $( \pm 11 \%, \mathrm{n}=27)$ of the $\mathrm{CaCO}_{3}$ standing stock dissolved per $24 \mathrm{~h}$.

The sea water at Stns 7,12 and 15 was 3.8 to 4.5 times oversaturated with respect to $\mathrm{CaCO}_{3}$. Even if all the POC in the samples had been mineralised to $\mathrm{CO}_{2}$

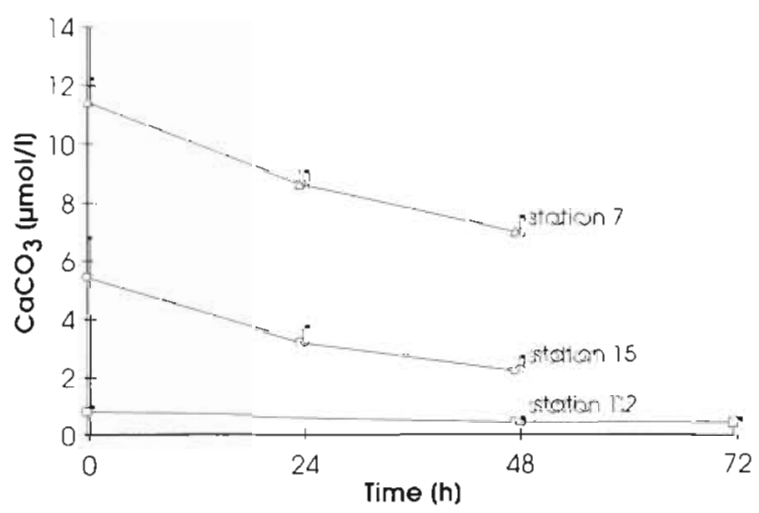

Fig. 4. Changes in standing stocks of $\mathrm{CaCO}_{3}$ of samples stored in the dark, with standard deviations. (ㄷ) Stn 12, (o) Stn 15, ( $\Delta) \operatorname{Stn} 7$ during the incubations the sea water would still be oversaturated 3.6 to 4.1 times with respect to $\mathrm{CaCO}_{3}$.

\section{Transect}

Within a period of $24 \mathrm{~h}$ vertical profiles were taken along a transect (Stns 20 to 33; Fig. 1A). This transect ran from the edge of the Atlantic Ocean, through the POC-rich zone, along the edge of the high reflectance area where coccoliths were abundant.

IIC and the density of the water (SigmaT) showed comparable patterns (Fig. 5A, B). Towards the high reflectance area the gradients of TIC and SigmaT with depth became more pronounced. An increased gradient of TIC with depth was noted above (in the section ' $24 \mathrm{~h}$ stations'), and indicates increased sedimentation. The $\mathrm{fCO}_{2}$ was clearly influenced by uptake of $\mathrm{CO}_{2}$ by algae, expressed as POC (Fig. 5C, D). A minimum of $f \mathrm{CO}_{2}$ was located in the POC-rich zone. Low values of $f \mathrm{CO}_{2}$ persisted in the high reflectance area. There was no apparent relationship between $\mathrm{CaCO}_{3}$ and $f \mathrm{CO}_{2}$ (Fig. 5D, E). Calculated alkalinity in the upper mixed layer decreased from the POC-rich zone to the high reflectance area. This agrees with the observed increase of the standing stock of $\mathrm{CaCO}_{3}$ (Fig. 5E, F).

The $\mathrm{CaCO}_{3}$ standing stock, as measured by atomic absorption, showed a close correlation with the $\mathrm{CaCO}_{3}$ standing stock calculated from flow cytometer data $\left(\mathrm{CaCO}_{3}{ }^{\mathrm{AAS}}=0.99 \mathrm{CaCO}_{3}{ }^{\text {flow cytometer }}-0.052, \mathrm{p}<0.001, \mathrm{n}\right.$ = 39). For Stns 20, 22, 30 and 32 we assumed that each Emiliania huxleyi cell was covered with 20 coccoliths. The total number of coccoliths (attached and detached) was multiplied by $0.26 \mathrm{pg} \mathrm{C}$ coccolith $^{-1}$ (Balch et al 1992). At Stns 24, 26 and 28 (the POC-rich zone) $\mathrm{CaCO}_{3}$ was calculated from detached coccoliths only, because the numbers of E. huxleyi cells were probably overestimated due to the presence of small diatoms (P. van der Wal, NIOZ, pers. comm.). At Stn 33 (95 nautical miles from the start of the transect) $\mathrm{CaCO}_{3}$ was not measured by atomic absorption spectrophotometry (AAS), but estimated using this equation.

The organic carbon to chlorophyll ratio [POC ( $\mu$ mol $\left.\mathrm{l}^{-1}\right)$ /chiorophyll a $\left.\left(\mu \mathrm{g} \mathrm{l}^{-1}\right)\right]$ was $6.7 \pm 3.8(\mathrm{n}=43)$ on average. In the POC-rich zone the ratio was $9 \pm 5(n=17)$. In the high reflectance area it was $4 \pm 2(n=15)$. Because organic carbon was calculated from flow cytometer data for living algae, the ratio is a direct measure of the average algal composition

Total carbon content (TIC + POC; Fig. 6) was calculated over the photic zone 10 to $40 \mathrm{~m}$, penetration depth of $0.5 \%$ of surface irradiance) and the aphotic zone ( 40 to $80 \mathrm{~m})$, and over the entire sampled depth $(0$ to $80 \mathrm{~m})$. Proceeding from the POC-rich zone towards the high reflectance area the total carbon content decreased in 

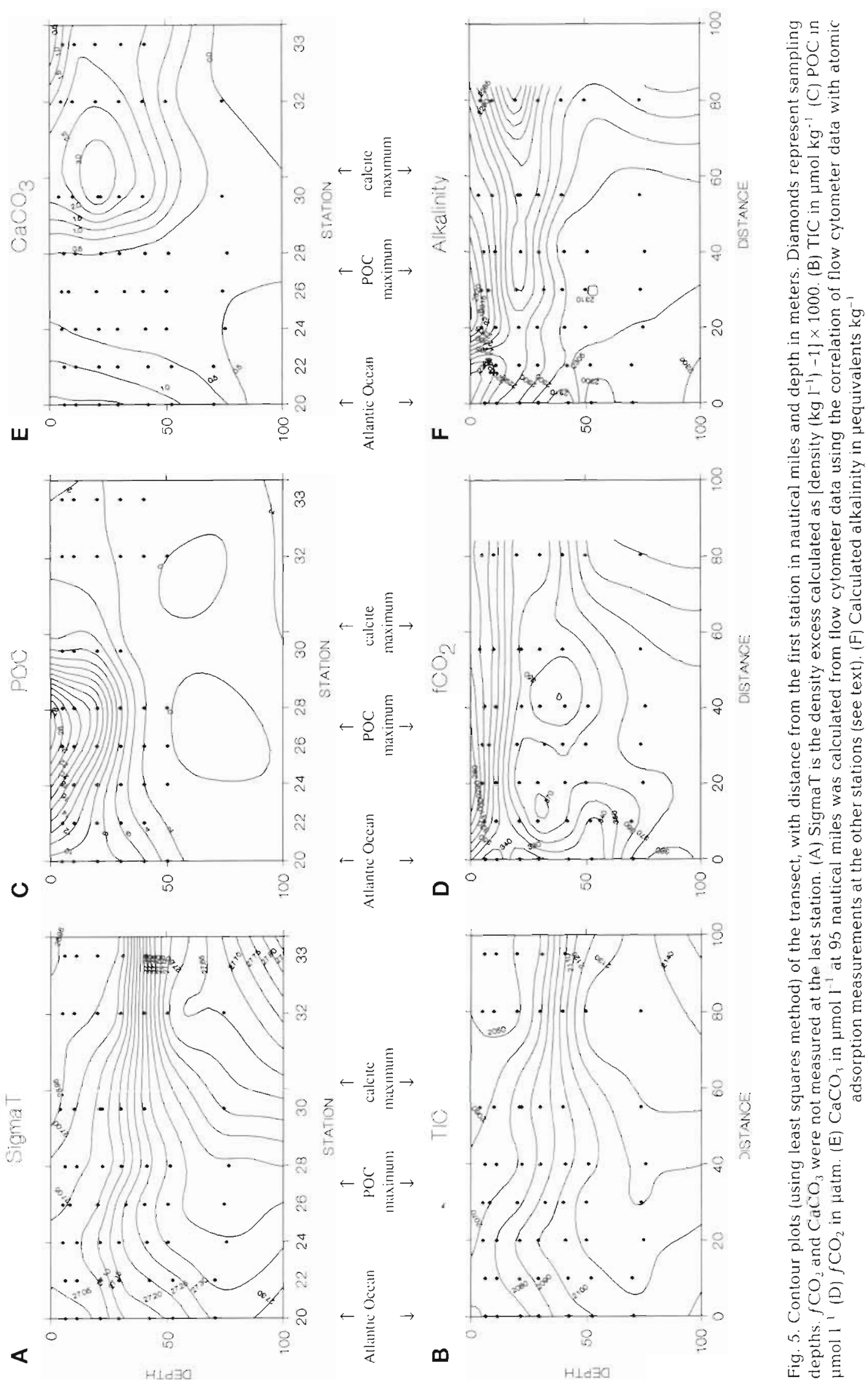


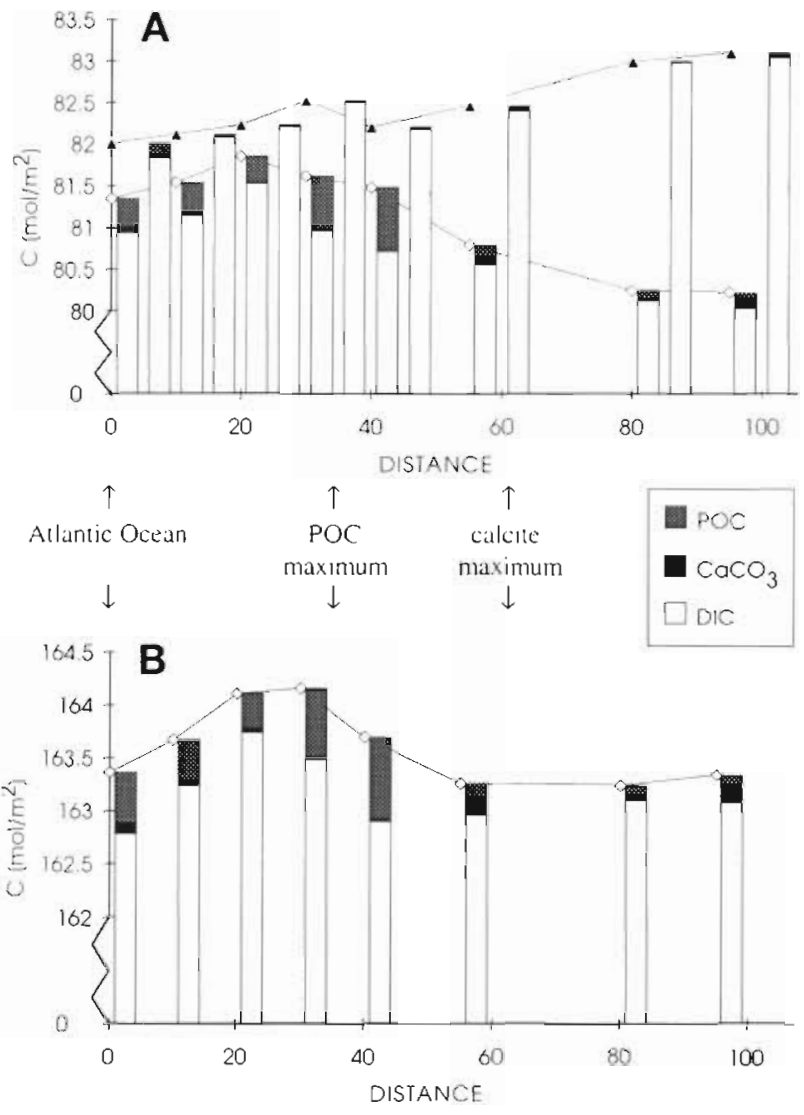

Fig. 6. Total carbon content ( $\Sigma \mathrm{C}$ : the sum of $\mathrm{TC}$ and POC) of the water column along the transect, with distance from the first station in nautical miles. Open bars: DIC. Filled bars: $\mathrm{CaCO}_{3}$. Shaded bars: POC. (A) $\diamond$ (odd bars) $\Sigma \mathrm{C}$ in the photic zone: 0 to $40 \mathrm{~m}$ depth. $\Delta$ (even bars) $\Sigma \mathrm{C}$ in the aphotic zone: 40 to $80 \mathrm{~m}$ depth. (B) $\Sigma \mathrm{C}$ in the sampled water layer: 0 to $80 \mathrm{~m}$ depth

the photic zone, whereas it increased in the aphotic zone (Fig. 6A). We ascribe these trends to the sinking of $\mathrm{CaCO}_{3}$ and $\mathrm{POC}$ through the stratified layer, and the subsequent dissolution of $\mathrm{CaCO}_{3}$ and degradation of POC below $40 \mathrm{~m}$. Van der Wal et al. (1995) found enhanced sedimentation of both $\mathrm{CaCO}_{3}$ and $\mathrm{POC}$ in the high reflectance area due to the increased density of faecal pellets that contained coccoliths.

Total carbon content measured over the entire sampled depth was highest in the POC-rich zone (Fig. 6B). Algal growth and the resultant minimum in $\mathrm{fCO}_{2}$ has probably led to a high atmosphere-ocean flux of carbon dioxide into this area. In the high reflectance area the total amount of $\mathrm{CaCO}_{3}$ exceeded the total amount of POC (Fig. 6B).

Dissolved organic carbon (DOC) was only measured in the photic zone. DOC was constant at $3.0 \pm 0.2 \mathrm{~mol}$ $\mathrm{m}^{-2}$ (C. P. D. Brussaard, NIOZ, pers. comm., data not shown).

\section{DISCUSSION}

In a bloom of Emiliania huxleyi in the North Atlantic in 1991 Robertson et al. (1994) found that the fugacity of $\mathrm{CO}_{2}\left(\mathrm{fCO}_{2}\right)$ was 15 Hatm higher in waters with high $\mathrm{CaCO}_{3}$ standing stocks $\left(>18 \mu \mathrm{mol} \mathrm{l}^{-1}\right)$ than in waters with low $\mathrm{CaCO}_{3}$ standing stocks $\left(<5.5 \mu \mathrm{mol} \mathrm{l^{-1 }}\right)$. We will argue here that while the short-term effect of $\mathrm{CaCO}_{3}$ precipitation was a rise in $\mathrm{fCO}_{2}$ due to a decrease in alkalinity, the long-term effect of this bloom of $E$. huxleyi was a decrease in $\mathrm{fCO}_{2}$ by enhanced sedimentation. First we discuss the influences that the physical properties of the water column and biological activities have on the concentrations of inorganic and particulate organic carbon and the speciation of the dissolved inorganic carbon system. Then we derive a carbon budget that shows that this bloom acted as a carbon sink for the atmosphere.

The influence of the physical structure was apparent from the similarity between the contour plots for total inorganic carbon (TIC) and the density of the water column (Fig. 6A, B). In the high reflectance area the stratification was more pronounced than in the northern part of the research area (Atlantic Ocean side). As a result the phytoplankton was mixed over shallower depths, and the concentration gradient of inorganic carbon was steeper (Fig. 5B, see also Fig. 6A). The enhancement of stratification is not necessarily the result of physical processes only. Emiliania huxleyi may generate a positive feedback for an increase of the temperature in the upper mixed layer: the reflectance of coccoliths may increase the temperature by light scattering (Holligan \& Balch 1991, Westbroek et al. 1993), this will make the upper mixed layer shallower which will increase the average light intensity, and this will stimulate growth. The observed positive correlation between temperature and the $\mathrm{CaCO}_{3}$ standing stock illustrates these processes of calcification, stratification and positive feedback.

The influence of biological activities on the carbon speciation was manifested by the occurrence of the $\mathrm{fCO}_{2}$ minimum in the POC-rich zone, and by the increase of $\mathrm{fCO}_{2}$ with biologically produced $\mathrm{CaCO}_{3}$. Furthermore TIC was strongly depleted in the upper mixed layer of the high reflectance area, because in this area sedimentation was high due to the elevated sinking speed of faecal pellets containing $\mathrm{CaCO}_{3}$ (van der Wal et al. 1995).

In a plot based on a surface survey over the entire cruise track, $\mathrm{fCO}_{2}$ (corrected to a constant temperature) increased with an increase of the standing stack of $\mathrm{CaCO}_{3}$ (Fig. 2). This demonstrates that precipitation of $\mathrm{CaCO}_{3}$ shifts the DIC equilibria in favour of $\mathrm{CO}_{2}$ according to Eqs. (2) and (3). The $f \mathrm{CO}_{2}$ increased 3.0 hatm per $\mu \mathrm{mol} \mathrm{l^{-1 }} \mathrm{CaCO}_{3}$. This is much 
higher than the increase of $f \mathrm{CO}_{2}$ that is predicted from $\mathrm{CaCO}_{3}$ precipitation $\left(1\right.$ uatm per $\mu \mathrm{mol} \mathrm{I}^{-1}$ $\mathrm{CaCO}_{3}$ ) at typical concentrations of alkalinity and DIC]. The enhanced increase results from the apparent inverse correlation between the standing stocks of POC and $\mathrm{CaCO}_{3}$ (Figs. 3C, D \& 5C, E). There are 3 compatible explanations for this inverse correlation. Firstly, the production of $\mathrm{CaCO}_{3}$ continues after the culmination of the bloom, so that the peak in $\mathrm{CaCO}_{3}$ standing stock occurs after the peak in POC standing stock (P. van der Wal pers. comm.). Secondly, other phytoplankton species may contribute relatively less to POC at the end of the bloom, when nutrient concentrations are low. At low nutrient concentrations Emiliania huxleyi will outcompete other phytoplankton species as it has a high affinity for nutrients, especially phosphate (Egge 1993). Thirdly, POC is degraded faster than $\mathrm{CaCO}_{3}$, so the relative contribution of $\mathrm{CaCO}_{3}$ increases.

The relatively high $f \mathrm{CO}_{2}$ in the surface water at Stn 15 (which has a high standing stock of $\mathrm{CaCO}_{3}$ ) is in accordance with the trend shown in Fig. 2. The profiles of the other $24 \mathrm{~h}$ stations do not show a clear increase of $f \mathrm{CO}_{2}$ with $\mathrm{CaCO}_{3}$. Other data also seem to contradict a positive correlation between $\mathrm{CaCO}_{3}$ and $f \mathrm{CO}_{2}$. A. $\operatorname{Stn} 7$, where the highest standing stock of $\mathrm{CaCO}_{3}$ was found, $f \mathrm{CO}_{2}$ was relatively low. Along the transect $\mathrm{fCO}_{2}$ at the surface was fairly constant between Stns 24 and 33. On-line surface measurements of $f \mathrm{CO}_{2}$ integrated over wider areas were lower inside the high reflectance area than in the reference areas. The explanation is found in the trend in TIC along the transect towards lower concentrations in the upper mixed layer and higher concentrations below the pycnocline. This is consistent with sedimentation, which results in a decrease of $f \mathrm{CO}_{2}$ at time scales that are slower than the increase of $\mathrm{fCO}_{2}$ caused by production of $\mathrm{CaCO}_{3}$. We conclude that whether calcification is seen as a sink or source of $\mathrm{CO}_{2}$ depends on the time scale on which these processes are observed: while on the basis of chemical equilibria production of $\mathrm{CaCO} 3$ will lead to an instantaneous increase of $f \mathrm{CO}_{2}$, the overall processes of production, remineralisation, dissolution, airsea gas exchange and sedimentation lead to a net export of carbon from the upper mixed layer, and hence a decrease of $f \mathrm{CO}_{2}$.

About $25 \%$ of the standing stock of $\mathrm{CaCO}_{3}$ was found to dissolve per $24 \mathrm{~h}$ in the dark, despite the fact that the sea water at Stns 7,12 and 15 was about 4 times oversaturated with respect to $\mathrm{CaCO}_{3}$. Degradation of the standing stock of POC would not change this. Since there was no significant difference between filtered (either 10 or $200 \mu \mathrm{m}$ ) and unfiltered samples, we conclude that dissolution was not caused by microor mesozooplankton. Therefore dissolution was prob- ably caused by respiration of bacteria and algae, and by lysis of cells, which creates an acidified micro-environment around the coccoliths.

Photosynthesis accompanied by production of $\mathrm{CaCO}_{3}$ in a molar ratio of $1: 1$ amounts to bicarbonate utilisation, and leads to a smaller decrease in $f \mathrm{CO}_{2}$ than in the case of $\mathrm{CO}_{2}$ utilisation by photosynthesis alone. In either case there is an additional decrease in $\mathrm{fCO}_{2}$ due to an increase in $\mathrm{pH}$ since uptake $\mathrm{NO}_{3}{ }^{-}$by the cell is coupled to $\mathrm{OH}^{-}$excretion (Brewer \& Goldman 1976). This increase of $\mathrm{pH}$ is equivalent to an increase of alkalinity (Table 1 ). The ratio between calcification and photosynthesis ( $\mathrm{C} / \mathrm{P}$ ratio) indicates how uptake of dissolved inorganic carbon will affect $f \mathrm{CO}_{2}$. When the effect of simultaneous production of $\mathrm{CaCO} 3$ and $\mathrm{POC}$ is calculated, $f \mathrm{CO}_{2}$ remains constant at a $\mathrm{C} / \mathrm{P}$ ratio of $1.2: 1$. When the effect of PON production is also taken into account the $\mathrm{C} / \mathrm{P}$ ratio required for maintaining a constant $f \mathrm{CO}_{2}$ increases to $1.3: 1$. The highest $\mathrm{C} / \mathrm{P}$ production ratio that was observed in this bloom was 0.18 (Stn 7, van der Wal et al. 1995). The highest C/P sedimentation ratio was 1.3 (Stn 15, the unpoisoned trap at $50 \mathrm{~m} \mathrm{depth}$; van der Wal et al. 1995). Thus no indication for an increase of $f \mathrm{CO}_{2}$ was observed at any stage of this bloom.

The particulate organic carbon to chlorophyll a ratio in the POC-rich zone was about twice the ratio in the high reflectance area. Although the difference is not significant, there is an explanation for this difference. The beam attenuation coefficient c530 was twice as large in the high reflectance area as in the POC-rich zone. This would lead to a higher chlorophyll content per cell as an adaptation to low light conditions.

Consecutive stages of the bloom development were encountered travelling southward along the transect. Therefore we tentatively interpret Fig. 6 as the development of the bloom in time. This interpretation is suggested by the seasonal northwesterly migration of the high reflectance area on satellite images taken before the cruise. This is corroborated by the observed decrease of nutrient concentrations from north to south. We have calculated the transport of carbon during the bloom from changes in the total carbon content (TIC + POC) of the sampled water column along the transect. For this purpose the water column was divided into an upper (0 to $40 \mathrm{~m})$, an intermediate $(40$ to $80 \mathrm{~m}$ ) and a deep ( 80 to $130 \mathrm{~m}$ ) box (Fig. 7). The thermocline resides at approximately $40 \mathrm{~m}$ depth (Fig. 5A), whereas no samples were taken below $80 \mathrm{~m}$ depth. The mass balance for the upper box involves an influx of $\mathrm{CO}_{2}$ from the atmosphere, changes in carbon pools and downflux of biogenic particles:

Influx $=\Delta \mathrm{DIC}+\triangle \mathrm{POC}+\Delta \mathrm{CaCO}_{3}+$ Downflux 
This latter downflux is the source term for a similar balance for the intermediate box, where any residual carbon is assumed to represent an excess sedimentation term into the deep box:

\section{Downflux $=$}

$$
\Delta \mathrm{DIC}+\triangle \mathrm{POC}+\Delta \mathrm{CaCO}_{3}+\text { Excess sedimentation }
$$

In the first 20 nautical miles of the transect from the Atlantic Ocean to the POC-rich zone the $\mathrm{fCO}_{2}$ decreased to $286 \mu$ atm at the surface, while the total carbon content from 0 to $80 \mathrm{~m}$ increased by $0.7 \mathrm{~mol} \mathrm{~m}^{-2}$ (Figs. 5D \& 6B). This indicates uptake of $\mathrm{CO}_{2}$ from the atmosphere. The air to sea flux (influx; Fig. 7) was calculated with the exchange coefficient for average wind speeds given by Wanninkhof (1992) using the average wind speed during the cruise and the $f \mathrm{CO}_{2}$ gradient at the chlorophyll maximum (20 nautical miles from the beginning of the transect). At a fugacity gradient of $72 \mu \mathrm{atm}$ and an average wind speed during the cruise of $7.7 \mathrm{~m} \mathrm{~s}^{-1}$ it would have taken $64 \mathrm{~d}$ for an amount of $0.7 \mathrm{~mol} \mathrm{~m}^{-2}$ to be taken up from the atmosphere. This $64 \mathrm{~d}$ period is only an approximation since $f \mathrm{CO}_{2}$ was only measured once at Stn 24 and the wind speed represents an average in time (13 d) and space. Blooms tend to be visible by AVHRR for shorter periods of typically 15 to $30 \mathrm{~d}$ (Westbroek et al. 1993). This would mean that either the air to sea flux has been underestimated or diffusion from below the thermocline plays an important role. We have not included the latter diffusion in our calculations.

In the subsequent stretch (20 to 100 nautical miles) from the POC-rich zone (Stn 24) to the high reflectance area (Stn 33) the stratification increased (Fig. 5A). As discussed above, this led to a decrease of DIC in the photic zone (0 to $40 \mathrm{~m}$; Fig. 6A). This decrease cannot be ascribed to increased photosynthesis since neither POC (Figs. 5C \& 6A), nor chlorophyll a (data not shown) increased, due to nitrogen limitation. Since the total carbon content in the aphotic zone increased while the total carbon content in the photic zone decreased (Fig. 6A) we assume that these changes are caused by sedimentation.

From the POC-rich zone to the high reflectance area the decrease in total carbon content of $1.6 \mathrm{~mol}$ $\mathrm{m}^{-2}$ in the upper mixed layer was larger than the increase of $0.9 \mathrm{~mol} \mathrm{m^{-2 }}$ in the intermediate layer (Fig. 6B). Since the upper mixed layer remained undersaturated (Fig. 5D), the difference of $0.7 \mathrm{~mol} \mathrm{~m}^{-2}$ cannot have escaped by sea to air outflux. The most straightforward explanation is that from $80 \mathrm{~m}$ to the bottom the total carbon content increased as well, as was found elsewhere at the $24 \mathrm{~h}$ stations at $125 \mathrm{~m}$ depth (Fig. 3). When the measured total carbon content at $80 \mathrm{~m}$ depth was extrapolated to the 80 to $130 \mathrm{~m}$ interval an increase of $2.4 \mathrm{~mol} \mathrm{~m}^{-2}$ for the aphotic zone $(40$ to $130 \mathrm{~m}$ ) was calculated over the whole transect (downflux + excess sedimentation in Fig. 7). In the photic zone the total carbon content decreased $1.1 \mathrm{~mol} \mathrm{~m}^{-2}$. This would yield an overall atmospheric carbon sink of $1.3 \mathrm{~mol} \mathrm{~m}^{-2}$ for this bloom of Emiliania huxleyi. This is consistent with the relatively high sedimentation rate of $45 \mathrm{mmol} \mathrm{m} \mathrm{m}^{-2} \mathrm{~d}^{-1}$ that was measured at Stn 7 (van der Wal et al. 1995), if it is multiplied by $30 \mathrm{~d}$.

If we calculate the global significance of this carbon sink of $1.3 \mathrm{~mol} \mathrm{~m}^{-2}$ by multiplying it by the average area of Emiliania huxleyi blooms of $1.4 \times 10^{6} \mathrm{~km}^{2}$ (Brown \& Yoder 1994) we arrive at $2.2 \mathrm{Mt} \mathrm{C} \mathrm{yr}^{-1}$ or $0.4 \%$ of the export production at $100 \mathrm{~m}$ depth (Berger et al. 1989)

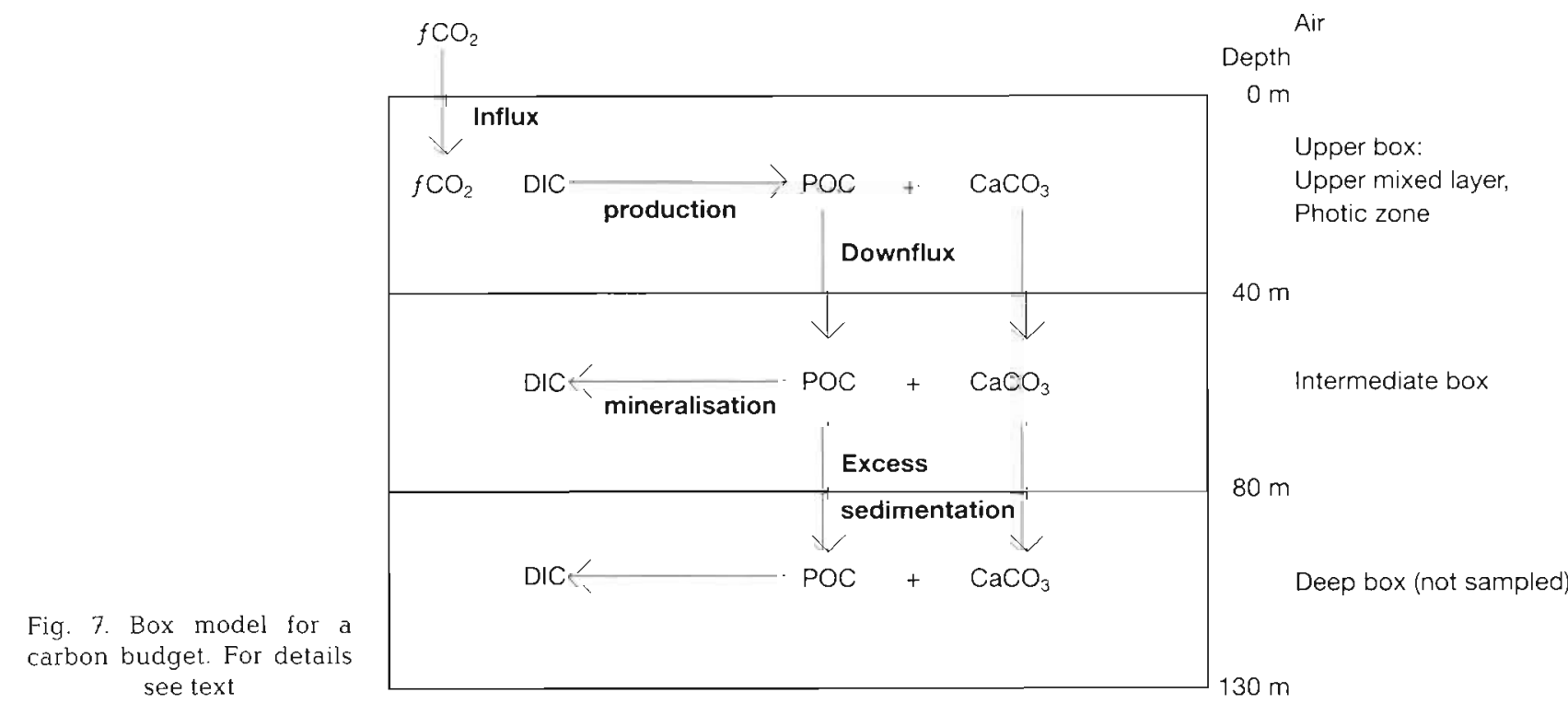


Acknowledgements. We thank Rob Kempers, Erica Koning and the captain and the crew of the RV 'Pelagia' for technical assistance. We thank the blood bank in Alkmaar for providing the Mailar. We thank Steve Groom for processing the AVHRR data. Helpful discussions with Erica Koning, Paul van der Wal, Hein de Baar, Dieter Wolff-Gladrow, Ray Weiss, Hein de Wilde and Bram Majoor were appreciated We thank the reviewers for comments that led to improvement of the manuscript.

\section{LITERATURE CITED}

Ackleson S, Balch WM, Holligan PM (1988) White waters of the Gulf of Maine. Oceanography 1(2):18-22

Balch W. Evans R, Brown J, Feldman G, McClain C, Esaias W (1992) The remote sensing of ocean primary productivity: use of a new data compilation to test satellite algorithms. J Geophys Res 97(C2):2279-2293

Berger WH, Smetacek VS, Wefer G (1989) Ocean productivity and paleoproductivity - an overview. In: Berger WH, Smetacek VS, Wefer $G$ (eds) Productivity in the ocean: present and past. John Wiley \& Sons Ltd, Chichester, p 1-34

Boden TA, Kaiser DP, Sepanski RJ, Stoss FW (1994) Trends '93: a compendium of data on global change. Carbon dioxide information analysis center, Oak Ridge National Laboratory, Oak Ridge, T'V

Brewer PG, Goldman JC (1976) Alkalinity changes generated by phytoplankton growth. Limnol Oceanogr 21(1): $108-117$

Brown CW, Yoder JA (1.994) Coccolithophorid blooms in the global ocean. J Geophys Res 99(C4):7467-7482

Campbell L, Vaulot D (1993) Photosynthetic picoplankton community structure in the subtropical North Pacific Ocean near Hawail (station ALOHA). Deep Sea Res 40(10):2043-2060

DOE (1991) Handbook of methods for the analysis of the various parameters of the carbon dioxide system in sea water Dickson AG, Goyet C (eds). US Department of Energy

Egge JK (1993) Nutrient control of phytoplankton growth: effects of macronutrient composition (N, P, Si) on species succession. PhD thesis, University of Bergen

Goyet C, Millero FJ, Poisson A, Shafer DK (1993) Temperature dependence of $\mathrm{CO}_{2}$ fugacity in seawater. Mar Chem 44:205-219

Goyet C. Poisson A (1989) New determination of carbonic acid dissociation constants in sea water as a function of temperature and salinity. Deep Sea Res 36(11): 1635-1654

Holligan PM, Balch WM (1991) From the ocean to cells: coccolithophore optics and biogeochemistry. In: Demers S (ed) Particle analysis in oceanography. NATO ASI G27 Springer-Verlag, New York, p 301-324

Holligan PM, Fernandez E, Aiken J, Balch WM, Boyd $P$, Burkill PH, Finch M, Groom SB, Malin G, Muller K, Purdie DA, Robinson C, Trees CC. Turner SMl van der Wal P (1993) A biogeochemucal study of the coccolithophore, Emiliania huxleyi, in the North Atlantic. Global Biogeochem Cycles 7(4):879-900

Mucci A. (1983) The solubility of calcite and aragonite in sed

This article was submitted to the editor water at various salinities, temperatures and one atmosphere total pressure. Am J Sci 283(7):780-799

Paasche E, Brubak S (1994) Enhanced calcification in the coccolıthophorid Emillania huxleyı (Haptophyceae) under phosphorus lımitation ?hycologia 33:324-330

Robertson JE, Robinson C, Turner DR, Holligan P, Watson AJ Boyd P, Fernandez E. Finch M (1994) The impact of a coccolithophore bloom on oceanic carbon uptake in the Northeast Atlantic during summer 1991 Deep Sea Res 41(2): $297-314$

Robertson JE, Watson AJ, Langdon C, Ling RD, Wood JW (1993) Diurnal variation in surface $\mathrm{pCO}_{2}$ and $\mathrm{O}_{2}$ at $60^{\circ} \mathrm{N}$, $20^{\circ} \mathrm{W}$ in the North Atlantic. Deep Sea Res 40(1/2):409=422

Strathmann RR (1967) Estimating the organic carbon content of phytoplankton from cell volume or plasma volume. Limnol Oceanogr 12:411-418

Takahashi M, Kikuchi K. Hara Y (1985) Importance of picocyanobacteria biomass (unicellular, blue-green algae) in the phytoplankton population of the coastal waters of Japan. Mar Biol 89:63-69

Takahashi T, Olafson J, Goddard JG, Chipman DW, Sutherland SC (1990) Ratio of the organic carbon and calcium carbonate productions observed at the JGOFS $47 \mathrm{~N}-20 \mathrm{~W}$ site. JGOFS report no. 7, SCOR, Halifax

van Bleijswijk JDL, Kempers ES, van der Wal P, Westbroek P, Egge JK, Lukk T (1994a) Standing stocks of PIC, POC, PON and Emiliania huxleyi coccospheres and liths in sea water enclosures with different phosphate loadings. Sarsia 79:307-317

van Bleijswijk JDL, Kempers RS, Veldhuis MJ (1994b) Cell and growth characteristics of types $A$ and $B$ of Emiliania huxleyi (Prymnesiophyceae) as determined by flow cytometry and chemical analyses. J Phycol 30:230-241

van der Wal P, Kempers RS, Veldhuis MJW (1995) Production and downward flux of organic matter and calcite in a North Sea bloom of the coccolithophore Emiliania huxleyi. Mar Ecol Prog Ser 126:247-265

Veldhuis MJW, Kraay GW, van Bleijswijk JDL (in press) Phytoplankton biomass, productivity and growth in the western Indian Ocean during the SW- and NE-monsoons. Deep Sea Res

Wanninkhof R (1992) Relationship between wind speed and gas exchange over the ocean. J Geophys Res 97:7373-7382

Wanninkhof R, Thoning K (1993) Measurement of fugacity of $\mathrm{CO}_{2}$ in surface water using continuous and discrete sampling methods. Mar Chem 44:189-204

Weiss RF (1974) Carbon dioxide in water and sea water: the solubility of a non-ideal gas. Mar Chem 2:203-215

Westbroek P, Brown C, van Bleijswijk J, Brownlee C, Brummer $G$, Conte $M$, Egge J, Fernández E, Jordan R, Knappertsbusch $M$, Stefels J, Veldhuis $M$, van der Wal $P$, Young J (1993) A model system approach to biological climate forcing. The example of Emilianıa huxleyi. Global Planet Change 8:27-46

Westbroek P, Young JR, Linschooten K (1989) Coccolith production (biomineralization) in the marine alga Emiliania huxleyl. J Protozool 36(4):368-373

Young JR, Didymus JM, Mann S (1991) On the reported presence of vaterite and aragonite in coccoliths of Emiliania huxleyi. Botanica Mar 34:589-591

Manuscript first recelved: November 29, 1994

Revised version accepted: July 24, 1996 